\title{
Development of Blast Disease Management Modules for Minimization of Tricycazole in Basmati Rice
}

\author{
Ramesh Singh Yadav* and Amit Kumar Yadav
}

Centre of Excellence for Sanitary and Phytosanitary (SPS), Department of Plant Pathology, Sardar Vallabhbhai Patel University of Agriculture \& Technology, Meerut 250110, India

*Corresponding author

\section{A B S T R A C T}

\section{Keywords \\ Fungicides, Rice blast, Biocontrol agents, Plant extract, Disease incidence, Yield and disease severity \\ Article Info \\ Accepted: 06 September 2018 Available Online: 10 October 2018}

A field experiment was laid out during Kharif 2014 and 2015. Objectives are to evaluate Tricyalzole fungicide, bio-agent and botanicals alone and with combination for the management of rice blast caused by Pyricularia oryzae in Randomized Block Design (RBD) with nine treatments and each treatment replicated thrice using susceptible rice variety PB 1121 at CRC research farm of Sardar Vallabhbhai University of Agriculture and Technology, Meerut. To minimize, Tricyclazole was sprayed at different concentration viz @ $0.03 \%, 0.06 \%$ and $0.12 \%$ alone and with combination of plant extract and bio agent. All the spray treatments proved effective and reduce blast incidence, severity and significantly increased the gain yield compared to control. Among the treatments Tricyclazole@0.03\%+Pseudomonas fluorescens -3@1 $@ 10^{8} \mathrm{cfu}+$ Beal leaf extract @ $10 \%$ proved significantly superior over rest of the treatments.

\section{Introduction}

Rice (Oriza sativa) is one of the most important food crop of India in area, production and productivity. Almost $90 \%$ of the rice is grown and consumed in Asia (Khush and Brar, 2002). The areas of western Uttar Pradesh, Haryana, Punjab and Uttrakhand states are major contributors of Basmati rice. The total area of Basmati in India is 1676.45 th/ha in which production of Basmati rice is 6612.04 th/tonne. The area and production of Basmati rice in Uttar Pradesh is 266.2 th/ha and 1260.69 th/tone respectively (AIREA, 2014). Its different varieties are mostly cultivated in the several districts of western Uttar Pradesh. The production of Basmati rice is attributed to several biotic and abiotic factors. Among the biotic factors disease is the most important factor which results in crop losses of $\$ 5$ billion every year (Asghar et al., 2007). Rice blast caused by pyricularia oryzae Cavara [synonym pyricularia grisea Sacc. The anamorph of Magnaporthe grisea (Herbert) Yaegashi and Udagawa], is one of the most destructive and wide spread disease (Jia et al., 2000). This disease has caused significant yield losses in many rice growing countries e.g. 75\% loss grains in India (Padmanabhan, 1965). It can affect all above ground parts of a rice plant leaf, coller, node, neck, parts of penicle and 
some time leaf sheath. Paddy Blast identify by initial symptoms appear as white grey-green lesion or spots, with dark green border. Older lesions on the leaves are elliptical or spindle shaped and whites to gray centers with red to brownish or necrotic border. During last few years the export of Basmati rice to USA and UK has been adversely affected by the presence of fungicidal residues of tricyclazole in food grains. United States blocked the Indian Basmati export due to presence of tricyclazole residues in food grains to the extent of 0.02-0.04 ppm. However, the residual concentration of tricyclazole was below its EU MRL of $1 \mathrm{ppm}$. The consignments were rejected as tricyclazole is not allowed United States. The fungicide residue problem of Basmati rice can be tackled through adoption of integrated disease management practices, by increasing awareness among the farmers about need based application of fungicides at recommended dosages and at proper time. Use of fungicides can be minimized by the integrated approach for management of plant diseases. Keeping this in view, efforts have been made to find out the efficacy of different doses of Tricyclazole with bio agent and plant extract on the management of blast disease in rice.

\section{Materials and Methods}

An experiment was conducted to evaluate efficacy of fungicides and bio-control agent in management of blast by determining different parameters like disease incidence, disease severity, and total grain yield. The experiment was conducted at Crop Research Centre of Sardar Vallabhbhai Patel University of Agriculture and Technology Modipuram, Meerut, U.P. The land was prepared by puddling method by applying one ploughing followed by two ploughing after one week. The plot size for each treatment was $3 \times 4 \mathrm{~m}^{2}$ with experiment was laid out in RBD with three replications. The fertilizers and other recommended cultivation practices were followed to raise good crop. The fungicides viz., Tricyclazole in different concentration @ $(0.0 .3 \%),(0.06 \%),(0.12 \%)$, botanical Beal leaf extract@(10\%) and Bio-agent Bacillus subtilis-13@1 x 10 $8 \mathrm{cfu} / \mathrm{ml}$ and Pseudomonas fluorescens-3@1 x 10 ${ }^{8}$ were sprayed. Disease scoring of blast was done after second application of the treatments, i.e. 75 days after transplanting selecting 10 hills of each plot following the standard scoring system developed by SES (2002). Diseases severity of blast was calculated by using the following formula from the data scored on a 0-9 scale.

Disease severity $(\%)=\frac{\text { Sum of all numerical reting }}{\text { Total number of plants observed } x \text { Maximum rating }(9)} \times 100$

Similarly, disease incidence was computed using the formula as below:

Disease incidence $(\%)=\frac{\text { Number of infected plants }}{\text { Total number of plants }} \times 100$

The yield of grains obtained from each net plot was recorded in kilograms after sun drying of grains and the grain yield per plot was converted into quintal per hectare.

\section{Results and Discussion}

In the present investigation foliar sprays with Tricyclzole, Pseudomonas fluorescens, Bacillus subtilis and Bael leaf extract were evaluated in possible combination to assess the integrated effect of these combinations on leaf blast severity, percent disease incidence and grain yield of rice. Field experiment was conducted during Kharif 2014-15 and 2015-16

\section{Kharif 2014-15}

The result of Kharif 2014-15 revealed that the minimum average percent disease severity and 
disease incidence was recorded $(9.37 \%)$ and $(10.67 \%)$ in (T6) Tricyclazole@0.03+ Pseudomonas fluorescens-3@1 x 10 + Beal leaf extract@10\% followed by spraying of (T3) Tricyclazole @ $0.12 \%$ i.e., (12.10\%) and $(11.33 \%)$ and spraying of combination of Triclazole@0.03\% + Bacillus subtilis13@1x10 ${ }^{8} \mathrm{cfu} / \mathrm{ml}+$ Beal leaf extract@(10\%) i.e., T7 (12.85\%) and $(13.33 \%)$ in Tricyclazole@0.06\% respectively.

The highest disease severity (15.10\%) was recorded in (T9) Bacillus subtilis -13@1 x 108 $\mathrm{cfu} / \mathrm{ml}$ and disease incidence $(20.33 \%)$ in both (T5) Beal leaf extract@ 10\% and (T9) Bacillus subtilis-13@1 x 10 8 cfu/ml compared with untreated control $(27.00 \%)$ and $(33.00 \%)$ respectively. The maximum yield $\mathrm{q} / \mathrm{ha}$ was recorded 47.33q/ha in (T3) Tricyclazole @ $0.12 \%$ followed by $46.67 \mathrm{q} / \mathrm{ha}$ in (T6) Tricyclazole@0.03+PS-3@1 x 10 + Beal leaf extract@10\% and minimum yield was recorded 35.00q/ha in Beal leaf extract@ 10\% compared to control $26.00 \mathrm{q} / \mathrm{ha}$

\section{Kharif 2015-16}

The result of Kharif 2015-16 revealed that the minimum average percent disease severity and disease incidence was recorded $(11.10 \%)$ and $(12.00 \%)$ in (T6) Tricyclazole@ 0.03+ Pseudomonas fluorescens-3@1 x 10 + Beal leaf extract@10\% followed by spraying of Triclazole@0.03\%+Bacillus subtilis13@1x10 cfu/ml + Beal leaf extract@10\% i.e., (12.33\%) and (13.16\%) in Tricyclazole @ 0.12 respectively. The maximum percent disease severity (14.65\%) was recorded in (T9) Bacillus subtilis-13@1 x 10 8 cfu/ml and disease incidence (18.94\%) compared with untreated control (25.00\%) and (29.51\%) respectively. The maximum yield $\mathrm{q} / \mathrm{ha}$ was recorded 38.83q/ha in (T6) Tricyclazole@ 0.03+ Pseudomonas fluorescens -3@1 x 10 + Beal leaf extract@ 10\% followed by $37.33 \mathrm{q} / \mathrm{ha}$ in (T3) Tricyclazole @ $0.12 \%$ and minimum yield was recorded $31.16 \mathrm{q} / \mathrm{ha}$ in Beal leaf extract@10\% compared to control 21.66q/ha.

The results of our studies are similar to earlier of several workers. Hesgde (2006) studied the efficacy of biological control agents and botanicals against rice blast (Pyricularia oryzae) in rice cv. HR-12. Among the biological control agents and botanicals, all biocidine, $P$. fluorescens and Neem Gold were found be most effective in the reduction of leaf blast (24.08, 24.43 and $23.85 \%$ incidence) respectively. Singh and Prasad (2007) reported tricyclazole (beam) as most effective fungicide for the control of rice blast and increase the yield. While, Vidhyasekaran et al., (1997) reported that when $P$. fluorescens applied as foliar spray, it suppresses rice blast in field condition.

In Basmati rice, economic losses from reduced yield are amplified by a severe deterioration in quality. Basmati varieties are more susceptible to these diseases and are a serious threat to Basmati production and had been reported to cause $20-50 \%$ loss in total production. Although these diseases can be managed by fungicides but using fungicides is not a good option as it usually left residue. To control these diseases, farmers are using tricyclazole, carbendazim, Isoprothiolane, Tebuconazole, Mancozeb and Streptocycline etc. Among these fungicides, Tricyclazole is most commonly used. Tricyclazole is a fungicide absorbed rapidly by roots and foliage for translocation in the plant body. But the tricyclazole left residue in Basmati rice grain which play a major role in rejection of Basmati rice consignment from USA and EU countries. USA allowed only tricyclazole residue level of over 0.1ppm, whereas EU had kept it at 1ppm and Japan had kept it at 3ppm. Hence forth, the exports to the niche US market have been badly hit due to the regulation on Tricyclazole content (Table 1). 
Table.1 Effect of different treatment for management of blast disease of rice

\begin{tabular}{|c|c|c|c|c|c|c|c|c|}
\hline \multirow[t]{2}{*}{ Treatments } & \multicolumn{2}{|c|}{$\begin{array}{l}\text { Average disease } \\
\text { severity }(\%)\end{array}$} & \multicolumn{2}{|c|}{$\begin{array}{l}\text { Average disease } \\
\text { incidence }(\%)\end{array}$} & \multicolumn{2}{|c|}{$\begin{array}{l}\text { Average yield } \\
\text { Q/ha }\end{array}$} & \multicolumn{2}{|c|}{$\begin{array}{l}\text { Increase yield } \\
\text { over control }(\%)\end{array}$} \\
\hline & 2014 & 2015 & 2014 & 2015 & 2014 & 2015 & 2014 & 2015 \\
\hline Tricyclazole@0.03\% & 14.37 & 13.65 & 23.00 & 19.38 & 35.67 & 31.33 & 27.10 & 45.20 \\
\hline Tricyclazole@0.06\% & 13.76 & 13.53 & 13.33 & 13.73 & 44.00 & 36.66 & 40.50 & 69.25 \\
\hline Tricyclazole@0.12\% & 11.10 & 13.56 & 11.33 & 13.16 & 47.33 & 37.33 & 45.06 & 69.86 \\
\hline $\begin{array}{l}\text { Pseudomonas fluorescens } 3 @ 1 x \\
10^{8} \mathrm{cfu} / \mathrm{ml}\end{array}$ & 13.33 & 13.85 & 18.00 & 17.00 & 40.33 & 35.00 & 35.53 & 54.50 \\
\hline Beal leaf extract@ 10\% & 12.37 & 13.45 & 20.33 & 17.22 & 35.00 & 31.16 & 25.71 & 46.15 \\
\hline $\begin{array}{l}\text { Triclazole@0.03\% + Pseudomonas } \\
\text { fluorescens3@1 x 10 + Beal leaf } \\
\text { extract@10\% }\end{array}$ & 9.37 & 11.10 & 10.67 & 12.00 & 46.67 & 38.83 & 44.28 & 75.34 \\
\hline $\begin{array}{l}\text { Triclazole@0.03\%+Bacillus subtilis- } \\
13 @ 1 \times 10^{8} \mathrm{cfu} / \mathrm{ml}+\text { Beal leaf extract@ } \\
(10 \%)\end{array}$ & 12.85 & 12.33 & 16.00 & 15.50 & 41.00 & 35.85 & 36.58 & 67.33 \\
\hline $\begin{array}{l}\text { Triclazole@0.03+ Bacillus substilis } \\
13 @ 1 \times 10^{8} \mathrm{cfu} / \mathrm{ml}+\text { Pseudomonas } \\
\text { fluorescens-3@1x10 } \mathrm{cfu} / \mathrm{ml}\end{array}$ & 14.65 & 13.76 & 15.00 & 15.87 & 42.50 & 36.41 & 38.82 & 69.23 \\
\hline Bacillus subtilis $13 @ 1 \times 10^{8} \mathrm{cfu} / \mathrm{ml}$ & 15.10 & 14.37 & 20.33 & 18.94 & 38.77 & 34.33 & 32.76 & 60.92 \\
\hline Control & 27.00 & 25.00 & 33.00 & 29.51 & 26.00 & 21.66 & - & \\
\hline CD at $(5 \%)$ & 1.55 & 0.85 & 0.78 & 1.76 & 1.76 & 2.23 & - & - \\
\hline
\end{tabular}


Thus, using minimum dose of appropriate fungicide with bio-agents, alternative to fungicide help in reducing health hazard by minimizing adverse impact on human health and environment.

\section{Acknowledgment}

The authors are greatly acknowledged to the Departments of Plant Pathology and Director Research of the University for constant support during experiments. The authors are also thankful to Director of Agriculture, Govt. of UP for sanctioning fund to establish Centre of Excellence for Sanitary and Phytosanitary (SPS) under RKVY scheme.

\section{References}

Asghar, A.H., Rashid, M., Ashraf, M.H., Khan and Chaudhry, A.Z. (2007) Improvement of basmati rice, against fungal infection through gene transfer technology. Pak. J. Bot. 39(4): 1277-83.

Hegde YR. 2006. Biological control of blast of rice. International Journal of Plant Sciences Muzaffarnagar 1(1): 99-100.
Jia, Y., Me Adams, S.A., Bryan, G.T., Hershay, H.P. and B. Valent 2000. Direct interaction of resistance genes products confers rice blast resistance. Embo. J. 19: 4004 - 4014.

Khush, G.S. And Brar, D.S., 2002. Biotechnology for rice breeding: progress and potential impact. In: proceeding of the 20th session of the international rice commission (23th 26th July, 2002, Bangkok, Thailand).

Padmanabhan SY (1965). Estimating losses from rice blast in India. In: The Rice Blast Disease, John Hopkins Press, Baltimore, Maryland. Pp. 203-221.

Singh G, Prasad CS (2007). Evaluation of fungicides against blast in basmati rice. Annals of Pl. Prot. Sci. 15(2): 514-515.

Vidhyasekaran P, Rabindran R, Muthamilan M, Nayar K, Rajappan K, Subramanian N, Vasumathi K (1997). Development of a powder formulation of Pseudomonas fluorescens for control of rice blast. Plant. Pathol. 46(3):291-297.

\section{How to cite this article:}

Ramesh Singh Yadav and Amit Kumar Yadav. 2018. Development of Blast Disease Management Modules for Minimization of Tricycazole in Basmati Rice. Int.J.Curr.Microbiol.App.Sci. 7(10): 777-781. doi: https://doi.org/10.20546/ijcmas.2018.710.086 